\title{
PENERAPAN PENDEKATAN CREATIVE PROBLEM SOLVING (CPS) PADA KONSEP "GAYA" UNTUK MENINGKATKAN HASIL BELAJAR SISWA
}

\author{
Neng Widiya Puspitasari \\ SDN Kalibuntu, Banten, Indonesia \\ e-mail: yawidiyapuspita89@gmail.com
}

\begin{abstract}
The purposes of the research are: 1. Describing the application of creative problem solving (CPS) approach on "gaya" concept study 2. Describing the improvement of students' learning result on through the use of student worksheet (LKS) as well as the problem solving through brainstorming by divergent and convergent thinking process. This research is a classroom action research (CAR) with two cycles. The previous research result, before applying this approach was only 12,25\% (5 students) who passed the minimum competence criteria. After researcher applying CPS approach in science study on konsep gaya, in the first cycle the number of students who passed competence increase to $52,50 \%$ (21 students). It shows that there is an improvement from the earlier data. It increases 40,25. In the second cycle the number of students who passed the competence increase to $77,30 \%$ (31 students). It means that the improvement of the percentage is 47,25 . Based on the data above, it can be concluded that the application of CPS approach can effectively improve students' achievement in SDN Kalibuntu.
\end{abstract}

Keywords: CPS approach, konsep gaya, students learning result

Abstrak: Tujuan penelitian ini adalah (1) Mendeskripsikan penerapan pendekatan Creative problem solving (CPS) pada pembelajaran konsep Gaya dikelas IV dengan jumlah 40 orang siswapada prembelajaran IPA di SDN Kalibuntu Kecamatan Baros Kabupaten Serang. (2) Mendeskripsikan peningkatan hasil belajar siswa pada konsep Gaya melalui penggunaan Lembar Kerja Siswa (LKS) serta pemecahan masalah melalui brainstorming (urun pendapat) melalui proses berpikir divergen dan konvergen. Penelitian ini merupakan penelitian tindakan kelas (PTK) yang di dalamnya terdapat dua siklus. Hasil penelitian menunjukkan sebelum menerapkan pembelajaran reflektif atau data awal siswa yang tuntas hanya $12,25 \%$ (5 orang). Setelah diterapkannya pendekatan creative problem solving (CPS) dalam pembelajaran IPA pada konsep gaya, pada siklus pertama siswa yang tuntas sebesar $52,50 \%$ (21 orang), sehingga ada peningkatan dari data awal dengan presentase sebesar $40,25 \%$. Pada siklus kedua jumlah siswa yang tuntas dengan presentase sebesar $77,50 \%$ (31 orang), dan mengalami peningkatan dari siklus pertama sebesar 47,25\%. Berdasarkan hasil penelitian dapat disimpulkan bahwa penerapan pendekatan creative problem solving (CPS) dapat meningkatkan hasil belajar siswa di SDN Kalibuntu, maka penelitian ini dapat dikatakan berhasil.

Kata kunci: Creative problem solving, gaya, IPA, PTK, brainstorming. 


\section{PENDAHULUAN}

Pada pengembangan kurikulum sains, merespon secara proaktif berbagai perkembangan inovasi, ilmu pengetahuan dan tekhnologi. Komptensi sains menjamin pertumbuhan keimanan dan ketaqwaan terhadap Tuhan Yang Maha Esa, penguasaan kecakapan hidup, penguasaan prinsip-prinsip alam, kemampuan bekerja dan bersikap ilmiah sekaligus pengembangan kepribadian bangsa Indonesia yang kuat dan berakhlak mulia. (Depdikbud,2004:18)

Berdasarkan observasi awal tentang pelaksanaan proses pembelajaran IPA di kelas IV SDN Kalibuntu Kecamatan Baros Kabupaten Serang menunjukkan masih jauhnya tujuan pelajaran sains dapat tercapai. Hal ini diindikasikan dari rendahnya pencapaian nilai siswa pada mata pelajaran IPA di kelas IV SDN Kalibuntu. Hal tersebut menjadi indikasi bahwa pembelajaran yang dilakukan selama ini belum efektif. Belum mencakup penampilan dan partisipasi siswa dalam pembelajaran, hingga sulit untuk mengukur keaktifan dan kreativitas siswa. Maka dari itu untuk memperbaiki hal tersebut perlu disusun suatu pendekatan dalam pembelajaran yang lebih komprehensif dan dapat meningkatkan kreativitas berpikir siswa dalam pemecahan masalah yang berkaitan dengan pembelajaran IPA.

Oleh karena itu penulis ingin menerapkan metode mengajar yang menarik dan tepat untuk era sekarang ini. Maka untuk itu penulis ingin menitikberatkan pada kegiatan siswa dimana siswa belajar secara aktif dan dapat mengembangkan kemampuan sendiri bersama kelompoknya. Karena pembelajaran yang terpusat pada guru sampai saat ini masih menemukan beberapa kelemahan. Kelemahan tersebut dapat dilihat pada saat berlangsungnya proses pembelajaran di kelas, interaksi aktif antara siswa dengan guru atau siswa dengan siswa jarang terjadi. Siswa kurang bisa bekerja dalam kelompok diskusi dan pemecahan masalah yang diberikan.

Creative problem solving merupakan langkah-langkah pembelajaran yang memfokuskan pada alur penyelesaian masalah secara kreatif (Suryosubroto:188) Parmes dalam Mulyoto (2005) mengemukakan adanya lima langkah yang melibatkan imajinasi dan pembenaran dalam menangani situasi dan pembahasan suatu masalah. Langkah-langkah crative problem solving tersebut bila diterapkan dalam pembelajaran adalah: 1) penemuan fakta, 2) penemuan masalah, berdasarkan fakta-fakta yang telah dihimpun, ditentukan masalah/pertanyaan kreatif untuk dipecahkan, 3) penemuan gagasan, menjaring sebanyak mungkin alternative jawaban untuk memcahkan masalah, 4) penemuan jawaban, sehingga ditemukan jawaban yang diharapkan, 5) penentuan penerimaan diketemukan kebaikan dan kelemahan gagasan, kemudian menimpulkan dari masing-masing masalah yang dibahas. Oleh karena itu dimungkinkan munculnya ide-ide siswa dalam menganggapi dan menyelesaikan permasalahan yang bermakna dan berkualitas sehingga kreativitas siswa dapat muncul dan berkembang.

Dengan adanya penelitian ini dapat dilihat bagaimana peningkatan hasil belajar siswa pada mata peajaran IPA pada konsep gaya dengan menggunakan metode creative problem solving (CPS) khususnya pada pemahaman gaya dan hasilnya dapat dijadikan sebagai upaya untuk pengembangan strategi mengajar sains di Sekolah 
Dasar. Peneliti tertarik dengan metode ini karena metode ini mengajak siswa berpikir secara terbuka dan kritis, sehingga dapat mengembangkan daya kreativitas siswa.

\section{KAJIAN TEORI}

Berdasarkan judul yang diambil peneliti, kajian teori yang dipakai antara lain pendekatan Creative problem solving, konsep gaya dan hasil belajar siswa.

Pendekatan "Creative problem solving" (CPS) adalah suatu pendekatan pembelajaran yang menekankan pada keterampilan pemecahan masalah. Ketika dihadapkan dengan suatu pertanyaan, siswa dapat melakukan keterampilan memecahkan masalah untuk memilih dan mengembangkan tanggapannya. Ketika dihadapkan pada suatu pertanyaan, siswa dapat melakukan keterampilan memecahkan masalah dengan memilih dan mengembangkan ide serta gagasannya. Tidak hanya dengan menghafal tanpa dipikir, keterampilan memecahkan masalah memperluas proses berpikir (Pepkin,2004:1).

Dalam pembelajaran IPA pendekatan creative problem solving cukup menarik untuk diterapkan. Pembelajaran dengan menerapkan pemecahan masalah secara kreatif memotivasi siswa-siswi dalam menyelesaikan masalah yang berhubungan dengan IPA secara kreatif, meningkatkan aktivitas dan kreativitas siswa, meningkatkan minat diskusi di antara siswa dan membantu kegiatan belajar untuk bisa lebih efektif dan berjalan baik.

Osborn (Cahyono,2007) mengemukakan bahwa model creative problem solving mempunyai tiga prosedur, antara lain:

1. Menemukan fakta, meliputi proses menjabarkan dan merumuskan masalah, mengumpulkan dan meneliti data serta informasi yang relevan.

2. Menemukan gagasan, yang berkaitan dengan memunculkan dan memodifikasi gagasan tentang bagaimana strategi yang harus dilakukan untuk memecahkan masalah.

3. Menemukan solusi, yaitu proses evaluatif sebagai puncak pemecahan masalah.

Langkah-langkah dalam pendekatan creative problem solving menurut William E. Mitchell dan Thomas F. Kowalk (Cahyono:2007) adalah sebagai berikut:

1. Mess-finding (menemukan masalah yang dirasakan sebagai pengganggu) tahap pertama merupakan suatu usaha untuk mengidentifikasi situasi yang dirasakan mengganggu.

2. Fact-finding (menemukan fakta) tahap kedua dilakukan dengan mendaftar semua fakta yang diketahui dan berhubungan dengan situasi tersebut untuk menjelaskan informasi yang tidak diketahui tapi essensial yang sedang diidentifikasi dan dicari.

3. Problem-finding (menemukan masalah) pada tahap menemukan masalah diupayakan siswa dapat mengidentifikasi semua kemungkinan pernyataan masalah dan kemudian memilih apa yang paling penting atau yang mendasari masalah.

4. Idea-finding (menemukan gagasan) pada tahap ini diupayakan untuk menemukan sejumlah ide dan gagasan yang mungkin dapat digunakan untuk memecahkan masalah. 
5. Solution-finding (menemukan solusi) pada tahap penemuan solusi, ide dan gagasan yang telah diperoleh pada tahap idea-finding diseleksi untuk menemukan ide yang paling tepat dalam memecahkan masalah.

6. Acceptance-finding pada tahap ini berusaha untuk memperoleh penerimaan atas solusi masalah, menyusun rencana tindakan dan mengimplementasi solusi tersebut.

Proses pemecahan masalah dimulai adanya input yang datang dari lingkungan atau dalam pribadi. Input tersebut diolah melalui berpikir secara divergen dengan tujuan berusaha mencari beberapa alternatif pemecahan. Setelah menentukan pilihan maka masuklah dalam produksi konvergen yang menghasilkan output. Dengan ketertiban lingkungan, perasaan, kesadaran, berpikir divergen dan konvergen maka tak dapat dipungkiri bahwa proses kreatif selalu menyertai pemecahan masalah.

Adapun langkah-langkah dalam pembelajaran pemecahan masalah secara kreatif (Suryosubroto, 2009: 200) adalah sebagai berikut:

1. Penemuan fakta (fact-finding)

2. Penemuan masalah (problem-finding)

3. Penemuan gagasan (idea finding), menjaring sebanyak mungkin alternatif jawaban untuk memecahkan masalah

4. Penemuan jawaban (solution-finding), penentuan tolok ukur atas kriteria pengujian jawaban, sehingga ditemukan kebaikan dan kelemahan gagasan, kemudian menyimpulkan dari masalah yang dibahas.

Secara operasional langkah-langkah pembelajaran yang dilakukan (Suryosubroto, 2009:200) adalah sebagai berikut:

1. Pembentukan kelompok (4-5 orang setiap kelompok).

2. Penjelasan prosedur pembelajaran (petunjuk kegiatan).

3. Pendidik menyajikan situasi problematik dan menjelaskan prosedur solusi kreatif kepada peserta didik (memberikan pertanyaan, pertanyaan problematik, dan tugas).

4. Pengumpulan data verifikasi mengenai suatu peristiwa yang dilihat dan dialami (dilakukan dengan mengumpulkan data di lapangan).

5. Eksperimental aternatif pemecahan masalah dengan diperkenankan pada elemen baru ke dalam situasi yang berbeda (diskusi dalam kelompok kecil).

6. Memformulasikan penjelasan dan menganalisis proses solusi kreatif (dilakukan dengan diskusi kelas yang didampingi oleh pendidik).

Berdasarkan uraian di atas, tampak jelas bahwa pembelajaran dengan menggunakan pendekatan creative problem solving dimulai oleh adanya masalah yang dalam hal ini dapat dimunculkan oleh guru (pendidik), kemudian siswa memperdalam pengetahuannya tentang apa yang mereka telah ketahui dan apa yang mereka perlu ketahui untuk memecahkan masalah tersebut. Siswa dapat memilih masalah yang 
dianggap menarik untuk dipecahkan sehingga mereka terdorong berperan aktif dalam belajar.

Dalam pembelajaran yang menerapkan CPS, peran pendidik lebih banyak menempatkan diri sebagai fasilitator, motivator dan dinamisator belajar baik secara individual maupun secara berkelompok. Proses pembelajaran yang memberikan kesempatan secara luas kepada pendidik merupakan prasyarat bagi perserta didik untuk berlatih belajar mandiri melalui CPS. Peran pendidik sebagai fasilitator, pendidik membantu memberikan kemudahan siswa dalam proses pembelajaran (langkah yang diperlukan menyajikan beberapa alternatif sumber belajar, langkah-langkah pembelajaran, menyediakan media pembelajaran). Sebagai motivator, pendidik berperan memotivasi siswa dalam melakukan kegiatan pembelajaran (memberikan penguatan sebagai umpan balik). Sebagai dinamisator, pendidik berusaha memberikan rangsangan (stimulans) dalam mencari, mengumpulkan dan menentukan informasi untuk pemecahan masalah berupa kondisi problematik dalam bentuk memberikan tugas dan memberikan umpan balik dalam pemecahan masalah.

Menurut Sudjana (2001:22) hasil belajar adalah kemampuan yang diperoleh siswa melalui kegiatan belajar. Hasil belajar dibagi menjadi tiga macam, yaitu: keterampilan dan kebiasaan, pengetahuan dan pengertian sikap dan cita-cita yang masing-masing golongan dapat diisi dengan bahan yang ada pada kurikulum sekolah. Lebih lanjut Sudjana menjelaskan mengenai hasil belajar merupakan suatu akibat dari proses belajar dengan menggunakan alat pengukuran yaitu berupa tes yang disusun secara terencana, baik tes tertulis, tes lisan maupun tes perbuatan. Dalam penelitian ini hasil belajar merupakan hal yang harus ditingkatkan, hal itu terkait dengan unsur-unsur lain, baik dari proses pembelajaran, peralatan atau sarana pendidikan, guru ataupun siswa itu sendiri yang terlibat secara langsung dalam proses pembelajaran. Maka peneliti bisa menyimpulkan bahwa dalam penelitian ini hasil belajar merupakan hal yang sangat krusial dan harus ditekankan, karena produk dari penelitian ini adalah peningkatan hasil belajar yang telah dicapai oleh siswa, yaitu berupa nilai tes, tingkat aktivitas siswa dan guru dalam pembelajaran yang dicuplik dari lembar observasi aktivitas guru dan siswa.

Materi pada penelitian ini difokuskan pada materi gaya. Adapun sub bab materi dalam penelitian ini meliputi gaya dapat mempengaruhi gerak benda, gaya dapat mengubah bentuk suatu benda dan gaya dapat mempengaruhi keadaan suatu benda dalam air. Materi konsep gaya disajikan melalui tiga tahapan yakni kegiatan apersepsi, kegiatan mengerjakan Lembar Kerja Siswa (LKS) secara per kelompok dan kegiatan pemecahan masalah secara kreatif melalui proses berpikir divergen dan konvergen secara per kelompok. Kegiatan apersepsi yakni percobaan yang berkaitan dengan konsep gaya. Kegiatan apersepsi tersebut dapat membimbing siswa untuk menemukan fakta yang berkaitan dengan konsep gaya. Melalui pengerjaan Lembar Kerja Siswa secara berkelompok, siswa dapat menemukan faktor-faktor yang dapat mempengaruhi gaya. Berdasarkan fakta-fakta yang telah dihimpun, siswa diberikan masalah yang sering kali dapat ditemukan dalam kehidupan sehari-hari yang berkaitan dengan konsep gaya untuk ditemukan solusi kreatif dari masalah tersebut melalui kegiatan 
diskusi kelompok dan berpikir secara divergen dan konvergen yang merupakan langkah-langkah dalam pembelajaran CPS.

\section{METODE}

Metode Penelitian yang digunakan yaitu Classroom Action Reseach. Rancangan penelitian yang digunakan sesuai dengan kidah-kaidah penelitian tindakan kelas. Penelitian tindakan kelas ini dilakukan sebagai upaya untuk perbaikan hasil belajar IImu Pengetahuan Alam pada konsep gaya di kelas IV dengan menggunakan pendekatan creative problem solving, melalui pemberian tindakan yang diawali dengan suatu perencanaan pembelajaran dan dilanjutkan dengan tindakan di kelas serta refleksi terhadap tindakan dan perencanaan awal setelah pembelajaran.

Pelaksanaan penelitian tindakan kelas terdiri dari 4 (empat) tahapan dasar yang saling terkait dan berkesinambungan, yaitu (1) perencanaan (planning), (2) pelaksanaan (acting), (3) pengamatan (observing), dan (4) refleksi (reflecting).

Pada peneltian ini dilaksanakan dalam beberapa siklus. Siklus I dilaksanakan dalam 4 kali pertemuan, selama 1 minggu dan siklus II 1 kali pertemuan. Kegiatankegiatan tersebut, dapat dijelaskan sebagai berikut:

\section{Perencanaan}

Pada tahap observasi dan wawancara disekolah, peneliti dapat menyimpulkan beberapa perencanaan tindakan yang akan dilakukan dalam menangani kendala yang ada di sekolah tersebut terutama permasalahan di kelas IV Sekolah Dasar Negeri Kalibuntu Kecamatan Baros Kabupaten Serang. Oleh karena itu, peneliti telah merencanakan tindakan yang akan dilakukan pada kegiatan pembelajaran. Berikut ini merupakan tahapan perencanaan tindakan yang akan dilakukan oleh peneliti yaitu: mengumpulkan data serta dokumen hasil belajar siswa, penyusunan rencana pembelajaran (RPP) yang sesuai dengan pendekatan CPS melalui kegiatan yang tidak menjenuhkan bagi peserta didik. RPP digunakan oleh guru sebagai acuan dalam menyelenggarakan proses kegiatan belajar mengajar. Penyusunan dan persiapan soal tes, persiapan sarana belajar, menyusun dan menyiapkan lembar observasi kegiatan proses belajar mengajar di kelas IV Sekolah Dasar Negeri Kalibuntu Kecamatan Baros Kabupaten Serang.

\section{Melaksanakan Tindakan}

Ditahap pelaksanaan tindakan, peneliti melakukan rencana kegiatan belajar mengajar dengan menerapkan pendekatan CPS seperti yang telah direncanakan sebelumnya di dalam Rencana Pelaksanaan Pembelajaran. Tindakan ini bersifat terbuka, dan sesuai dengan kejadian yang terjadi dalam proses kegiatan belajar mengajar.

\section{Observasi}

Observasi ini dilaksanakan oleh peneliti dan teman sejawat pada saat kegiatan belajar berlangsung di kelas. Kegiatan ini dimaksudkan untuk mengamati jalanya proses kegiatan belajar mengajar di dalam kelas. Berdasarkan hasil diskusi dengan teman sejawat dan masukan yang diberikan, maka peneliti mampu menyimpulkan 
kendala yang dialami oleh siswa tentang tingkat pemahaman mereka pada pelajaran IPA dengan topik gaya yang disampaikan oleh guru.

Sedangkan penampilan guru ketika mengajar atau melaksanakan pembelajaran di kelas dapat dilakukan dengan pengamatan kinerja guru dengan menggunakan lembar supervisi guru yang dilakukan oleh teman sejawat sehingga segala hal yang menyangkut materi dapat terekam secara optimal.

\section{Refleksi}

Hasil yang diperoleh dalam tahap observasi kemudian dikumpulkan dan dianalisa dalam tahap ini peneliti dan teman sejawat me-review apa yang telah dilakukan siswa dalam kegiatan pembelajaran. Berdasarkan hasil observasi dapat merefleksikan diri dengan melihat data observasi yang didapat, apakah kegiatan yang telah dilakukan dapat meningkatkan pemahaman dan kemampuan siswa. Dalam menyelesaikan soal pemecahan masalah dalam pembelajarandengan menggunakan alat peraga benda konkret atau benda nyata. Bila hasil pembelajaran kurang memuaskan, peneliti akan menyempurnakan rancangan pembelajaran secara lebih baik dan optimal. Hal ini dijadikan sebagai dasar perbaikan dalam perencanaan kegiatan yang akan dilaksanakan pada siklus II.

Minimal 70\% sampai 80\% dari jumlah siswa hasil belajarnya mencapai nilai 65 . Kriteria keberhasilan ini sesuai dengan KKM di kelas IV SDN Kalibuntu. Dalam penelitian tindakan kelas pasti terkait dengan data dan sumber data yang dihasilkan, data dalam penelitian tindakan ini meliputi data kuantitatif yaitu berupa data yang diambil dari data pengamatan tindakan dan hasil belajar IPA siswa yang diperoleh dengan menggunakan tes tertulis berbentuk essai. Sedangkan data kualitatif diperoleh dari hasil pengamatan atau observasi oleh teman sejawat selama proses pembelajaran.

Sumber data dalam pelaksanaan penelitian ini adalah siswa kelas IV SDN Kalibuntu Kecamatan Baros Kabupaten Serang sebagai objek penelitian yang berjumlah 40 siswa, terdiri dari laki-laki 12 perempuan 28 yang dijadikan penelitian tentang hasil belajar IPA pada materi konsep gaya.

\section{HASIL PENELITIAN}

Dari keempat pelaksanaan tindakan utama yang merupakan metode dari Classroomaction research dilaksanakan selama dua siklus pembelajaran. Dari setiap siklus pembelajaran dilakukan dua kali pertemuan sehingga masing-masing siklus terdiri dari dua kali pertemuan dengan fokus objek pengamatan yang berbeda.

\section{Pra Siklus}

Kegiatan yang dilaksanakan pada tahap pra siklus yaitu melakukan observasi secara mendalam dan refleksi hasil pembelajaran, menganalisis silabus dan materi pembelajaran, melakukan pembelajaran yang rutin dilakukan melalui metode ceramah/ konvensional, melakukan tes evaluasi pra siklus.

Data awal tentang hasil belajar IPA siswa SDN Kalibuntu, diperoleh dengan melakukan observasi awal berupa deskripsi data observasi awal sebelum tindakan yang terdiri tiga tindakan. Pertama tes awal hasil belajar IPS pada siswa kelas IV SDN 
Kalibuntu, kemudian kedua adalah observasi awal pelaksanaan proses pembelajaran yang dilakukan oleh guru kelas IV, serta mengidentifikasi peluang-peluang untuk menerapkan pendekatan Creative Problem Solvingdalam pembelajaran IPA. Ketiga melakukan wawancara dengan guru serta kepala sekolah mengenai bagaimana pembelajaran yang dilakukan guru selama ini di kelas.

Berdasarkan data tersebut menunjukkan bahwa pemahaman siswa terhadap materi pelajaran IPA yang ditunjukkan dengan hasil belajar siswa sebelum tindakan penelitian dilakukan masih rendah, belum sesuai dengan harapan. Hasil pengamatan kegiatan pembelajaran menunjukkan bahwa sebagian besar sikap belajar siswa terhadap proses dan hasil pembelajaran masih pasif dan motivasi belajar yang rendah, hal ini dapat dilihat dari kurang bersemangatnya siswa dalam mengikuti kegiatan pembelajaran, keaktifan bertanya dan menjawab pertanyaan yang masih sangat rendah. Rendahnya motivasi belajar siswa tersebut berdampak negatif pada hasil belajar siswa yang masih rendah.

\section{Deskripsi Data Siklus I}

Tahapan pelaksanaan siklus I terdiri dari perencanaan, pelaksanaan, observasi, dan refleksi, yang dapat diuraikan sebagai berikut:

a. Perencanaan

Pada siklus I ini, peneliti melakukan perencanaan kegiatan pembelajaran sebagai berikut:

1) Membuat rencana pelaksanaan pembelajaran untuk siklus pertama pada standar kompetensi dan kompetensi dasar tentang menyimpulkan hasil percobaan bahwa gaya (dorongan/tarikan) dapat mengubah suatu benda.

2) Menentukan skenario pembelajaran melalui pendekatan creative problem solving.

3) Mempersiapkan sumber, bahan, dan alat bantu yang dibutuhkan untuk melakukan percobaan tentang gaya (mobil-mobilan, tali plastik, pesawat kertas, dan bola sepak).

4) Menyiapkan format pengamatan berupa lembar observasi terhadap guru, lembar observasi terhadap siswa, Lembar Kerja Siswa (LKS) dan soal evaluasi.

b. Pelaksanaan Tindakan (Acting)

Kegiatan tindakan ini dilakukan oleh peneliti tanggal 2 Mei 2018. Kegiatan ini dimaksudkan untuk melaksanakan pembelajaran IPA pada konsep materi gaya dengan menggunakan pendekatan CPS. Adapun langkah-langkah pembelajaran sebagai berikut:

Kegiatan Awal

Guru masuk kelas pada jam pelajaran IPA dan memberi salam yang kemudian salam tersebut dijawab oleh siswa-siswi kelas IV. Sebelum pelajaran dimulai, guru dan siswa bersama-sama membaca doa. Guru mengabsen siswa untuk mengecek siswa yang hadir dan yang tidak hadir. Guru melakukan kegiatan apersepsi di depan kelas 
sebagai berikut: melakukan orientasi pemusatan perhatian siswa dengan melakukan demonstrasi menarik mobil-mobilan dengan seutas tali. Kemudian guru bertanya kepada siswa: Apa yang terjadi dengan mobil-mobilan tersebut? Siswa menjawab: Mobil-mobilan tersebut bergerak. Kemudian guru bertanya kepada siswa: Apa yang menyebabkan mobil-mobilan tersebut berubah dari semula diam menjadi bergerak? Siswa menjawab: Tarikan pada tali plastik. Guru bertanya apa yang menyebabkan pesawat kertas terbang? Siswa menjawab dorongan. Guru bertanya kepada siswa: Apa yang dimaksud dengan gaya yang dapat kalian artikan dari kegiatan demonstrasi yang telah ibu lakukan di depan kelas? Siswa menjawab: Gaya adalah tarikan atau dorongan. Guru bertanya apa hubungannya gaya dengan gerak benda? Siswa menjawab: Gaya dapat mengubah gerak benda.

Guru menjelaskan bahwa materi yang akan dipelajari pada pertemuan ini adalah materi konsep gaya. Guru menjelaskan ada beberapa jenis gaya yakni gaya tarik, gaya dorong dan gaya gravitasi bumi. Selanjutnya guru membagi siswa kedalam 8 kelompok (masing-masing kelompok terdiri dari 5 orang siswa) kemudian memberi nama kelompok tersebut kelompok satu dan seterusnya.

Selanjutnya guru menyajikan fakta yang ditemukan. Melalui kegiatan apersepsi yang telah dilakukan guru di depan kelas. Dari kegiatan apersepsi tersebut guru membimbing siswa untuk menemukan fakta bahwa gaya dapat mempengaruhi gerak benda. Setelah guru dapat membimbing siswa untuk menemukan fakta bahwa gaya dapat mengubah gerak benda, guru meminta secara berkelompok menuliskan berbagai gerak benda yang dapat siswa temukan dalam kehidupan sehari-hari melalui Lembar Kerja Siswa (LKS). Dari daftar gerak benda tersebut siswa menganalisis faktor-faktor yang mempengaruhi gerak benda tersebut.

Kemudian siswa menemukan masalah berdasarkan fakta-fakta yang telah dihimpun, guru menentukan masalah atau pertanyaan kreatif untuk dipecahkan oleh siswa bersama kelompoknya. Adapun masalah yang harus dipecahkan adalah: Bagaimana caranya agar buah jambu air yang sudah matang tidak jatuh ke tanah karena gaya gravitasi bumi?

Selanjutnya siswa menemukan gagasan, pada kegiatan ini siswa menjaring sebanyak mungkin alternatif jawaban untuk memcahkan masalah melalui berpikir divergen melalui kegiatan brainstorming (urun pendapat) di dalam kelompok. Siswa secara kelompok diminta mencari dan menuliskan 10 ide yang bisa dijadikan solusi agar buah jambu tidak jtuh ke tanah akibat pengaruh gaya gravitasi bumi dengan tidak mengabaikan aturan-aturan berpikir divergen, yakni tidak memberikan komentar buruk terhadap teman yang sedang mengungkapkan idenya dalam kegiatan brainstorming.

Kemudian siswa menemukan jawaban melalui proses berpikir konvergen. Setelah siswa menuliskan 10 ide yang didapat dari berpikir divergen, kemudian siswa memikirkan kembali ide-ide yang benar-benar masuk akal dan dapat dijadikan solusi.

Kegiatan akhir

Setelah selesai melakukan kegiatan brainstorming, guru mengarahkan siswa untuk menarik kesimpulan dari apa yang didiskusikan dalam kerja kelompok tersebut. 
Guru menyimpulkan kembali materi yang telah diajarkan. Ini dilakukan agar siswa paham betul materi yang telah diajarkan. Guru dan siswa memeriksa LKS dan memberikan komentar mengenai kekurangan siswa dalam jawaban LKS. Guru dan siswa melakukan tanya jawab sebagai respons terhadap kemampuan siswa dalam proses pembelajaran yang dilakukan. Guru memberikan pujian kepada para siswa yang telah melakukan kegiatan pembelajaran dengan baik dalam diskusi kelompok maupun ketika menjawab pertanyaan dalam tahap tanya jawab dan menanyakan tentang proses pembelajaran yang sudah dilakukan apakah menyenangkan bagi siswa atau tidak. Siswa secara spontan mengatakan bahawa pembelajaran hari ini menarik. Kemudian guru menutup pelajaran dengan memberikan evaluasi dan mengucapkan salam.

\section{Deskripsi data Siklus II}

\section{a. Perencanaan}

Kegiatan ini dilakukan peneliti bersama guru merencanakan rencana pembelajaran dari hasil observasi dan refleksi dari kegiatan siklus I sebagai wujud dari refleksi kelemahan yang terjadi pada siklus I. kegiatan yang dilaksanakan pada tahap ini adalah menyusun perangkat pembelajaran (RPP) konsep gaya di kelas IV dengan menggunakan metode creative problem solving pada materi gaya dapat mengubah bentuk suatu benda. Kemudian membuat alat bantu mengajar, seperti alat peraga dan media pembelajaran, serta membuat pedoman lembar observasi aktivitas guru dan siswa dan membuat soal evaluasi tes tertulis yakni tes uraian.

\section{b. Tindakan}

Kegiatan tindakan ini dilaksanakan pada tanggal 9 Mei 2018. Kegiatan ini dimaksudkan untuk melaksanakan pembelajaran IPA pada konsep gaya dengan menggunakan pendekatan creative problem solving. Dengan langkah pembelajaran sebagai berikut:

\section{Kegiatan awal}

Guru masuk kelas pada jam pelajaran IPA dan memberi salam yang kemudian salam tersebut dijawab oleh siswa. Sebelum pelajaran dimulai, guru dan siswa bersama-sama membaca doa. Doa dipimpin oleh ketua kelas kemudian diikuti siswa yang lain. Guru mengabsen siswa untuk mengecek siswa yang tidak hadir. Guru membagi siswa ke dalam 8 kelompok (masing-masing kelompok terdiri dari 5 orang siswa) kemudian memberi nama kelompok tersebut kelompok satu dan seterusnya. Kegiatan pendahuluan yakni melakukan kegaitan apersepsi sebagai berikut: Guru melakukan orientasi pemusatan perhatian siswa dengan melalukan demonstrasi membentuk tanah liat menjadi bentuk menyerupai bola, kemudian menekannya di atas papan dan memberi gaya tekan dengan telapak tangan. Kemudian guru bertanya kepada siswa: Apa yang terjadi pada tanah liat tersebut? Siswa menjawab: Tanah liat berubah bentuk menjadi pipih. Guru bertanya kepada siswa: Apa yang menyebabkan 
tanah liat tersebut berubah bentuk menjadi pipih? Siswa menjawab: Gaya tekan. Guru bertanya kepada siswa: Apa yang kalian simpulkan dari demonstrasi yang ibu lakukan tadi? Siswa menjawab: Gaya dapat menyebabkan berubahnya bentuk benda.

Kemudian guru menyajikan fakta yang ditemukan. Melalui kegiatan apersepsi yang telah dilakukan yakni membentuk tanah liat menjadi bentuk menyerupai bola, kemudian menekannya di atas papan dan memberi gaya tekan dengan telapak tangan. Dari kegiatan apersepsi tersebut guru membimbing siswa untuk menemukan fakta bahwa gaya dapat mengubah bentuk benda. Setelah dapat menemukan fakta bahwa gaya dapat mengubah bentuk benda, siswa secara kelompok menuliskan contoh peristiwa sehari-hari yang menggunakan gaya untuk mengubah bentuk suatu benda pada LKS. Dari daftar contoh peristiwa tersebut, siswa menganalisis faktor-faktor yang mengubah bentuk benda tersebut. Selanjutnya guru menemukan masalah, berdasarkan fakta-fakta yang telah dihimpun ditentukan masalah atau pertanyaan kreatif untuk dipecahkan oleh siswa. Adapun masalah yang harus dipecahkan siswa secara bersama adalah: Bagaimana caranya agar celengan yang terbuat dari tanah liat tidak mudah pecah.

Kemudian siswa menemukan gagasan, siswa menjaring sebanyak mungkin alteratif jawaban untuk memecahkan masalah melalui proses berpikir divergen melalui kegiatan brainstorming (urun pendapat) di dalam kelompok. Siswa secara kelompok diminta mencari dan menuliskan minimal 10 ide yang bisa dijadikan solusi agar celengan yang terbuat dari tanah liat tidak mudah pecah. Selanjutnya siswa menuliskan jawaban, melalui proses berpikir konvergen. Setelah siswa menemukan sebanyak mungkin ide, kemudian siswa memikirkan kembali ide-ide yang telah siswa tulis. Kemudian siswa memilih ide yang benar-benar dapat dijadikan solusi, siwa diminta menuliskan 3 ide yang benar-benar dijadikan solusi.

Kegiatan akhir

Setelah selesai melakukan kegiatan brainstorming, guru mengarahkan siswa untuk menarik kesimpulan dari apa yang didiskusikan dalam kerja kelompok tersebut. Guru menyimpulkan kembali materi yang telah diajarkan. Ini dilakukan agar siswa paham betul materi yang telah diajarkan. Guru dan siswa memeriksa LKS dan memberikan komentar mengenai kekurangan siswa dalam LKS tersebut. Guru dan siswa melakukan tanya jawab sebagai respons terhadap kemampuan siswa dalam proses pembelajaran yang dilakukan. Guru memberikan pujian kepada para siswa yang telah melakukan kegiatan pembelajaran dengan baik dalam diskusi kelompok maupun ketika menjawab pertanyaan dalam tahap tanya jawab dan menanyakan tentang proses pembelajaran yang sudah dilakukan apakah menyenangkan bagi siswa atau tidak. Siswa secara spontan mengatakan bahawa pembelajaran hari ini menarik. Kemudian guru menutup pelajaran dengan memberikan evaluasi dan mengucapkan salam.

Selama proses pembelajaran berlangsung, peneliti dan teman sejawat mengamati secara teliti hasil proses pembelajaran dari siklus I dan siklus II. Dari pengamatan peneliti dan teman sejawat terjadi peningkatan hasil belajar IPA pada 
siswa kelas IV SDN Kalibuntu. Dapat diketahui bahwa secara umum kegiatan pembelajaran sudah sangat baik dari guru maupun siswa.

c. Observasi

Observasi dilakukan untuk mengamati pelaksanaan kegiatan pembelajaran. Pengamatan dilakukan terhadap guru dan siswa pada saat kegiatan pembelajaran berlangsung.

1) Pengamatan terhadap guru

Berdasarkan hasil pengamatan terhadap guru yang dilakukan oleh kolaborator, diperoleh data seperti pada Tabel 1.

Tabel 1. Prosentase Hasil Obervasi Terhadap Guru Pada Siklus II

\begin{tabular}{lcc}
\hline Aktivitas Guru & Skor & Prosentase \\
\hline Melakukan Pembelajaran & 35 & $25 \%$ \\
Mengelola interaksi kelas & 23 & $16 \%$ \\
Mendemontrasikan kemampuan khusus & 22 & $16 \%$ \\
Melaksanakan Penilaian & 11 & $8 \%$ \\
Kesan umum pelaksanaan pembelajaran & 15 & $11 \%$ \\
\hline Jumlah & 106 & $76 \%$ \\
\hline
\end{tabular}

Dari data hasil observasi terhadap guru yang telah diuraikan di atas, diketahui bahwa dari 28 aspek pengamatan diketahui bahwa jumlah skor hasil pengamatan diperoleh sebesar 106 dari skor ideal sebesar 140 artinya skor yang diperoleh guru dalam kegiatan pembelajaran sudah mencapai skor ideal. Jadi kinerja guru dalam kegiatan pembelajaran sudah masuk dalam kategori baik. Dari beberapa aspek yang belum berhasil pada siklus I telah diperbaiki dan ditingkatkan pada siklus II sehingga kinerja guru dalam melaksanakan pembelajaran telah sesuai dengan harapan.

2) Pengamatan terhadap siswa

Berdasarkan hasil pengamatan terhadap siswa yang dilakukan oleh teman sejawat, diperoleh data seperti pada Tabel 2.

Tabel 2. Hasil Obervasi Terhadap Siswa Pada Siklus II

\begin{tabular}{lcc}
\hline Aktivitas Belajar & Banyak Siswa & Prosentase \\
\hline Tinggi & 9 & $22,5 \%$ \\
Sedang & 21 & $52,5 \%$ \\
Rendah & 10 & $25 \%$ \\
\hline Jumlah & 40 & $100 \%$ Ketuntasan $(75 \%)$ \\
\hline
\end{tabular}


3) Hasil tes evaluasi

Berdasarkan hasil tes evaluasi untuk mengukur pemahaman siswa terhadap materi pelajaran yang telah disampaikan, diperoleh data seperti pada Tabel 3.

Tabel 3. Hasil Tes Evaluasi Siklus II

\begin{tabular}{ccccl}
\hline No & Nilai & Frekuensi & Prosentase & Keterangan \\
\hline 1 & $50-54$ & 1 & $2,5 \%$ & Rendah \\
2 & $55-64$ & 4 & $10 \%$ & Rendah \\
3 & $65-74$ & 11 & $27,5 \%$ & Sedang \\
4 & $75-84$ & 18 & $45 \%$ & Sedang \\
5 & $85-100$ & 6 & $15 \%$ & Tinggi \\
\hline Jumlah & 40 & Siswa Blm Tuntas & 9 \\
\hline Nilai Rata-rata & 75 & Siswa Tuntas & 31 \\
\hline
\end{tabular}

\section{d. Refleksi}

Hasil pengamatan dan evaluasi pada siklus II menunjukkan bahwa dengan penggunaan pendekatan creative problem solving dapat meningkatkan hasil belajar dalam kegiatan pembelajaran yang berdampak pada peningkatan pemahaman dan hasil belajar siswa tentang konsep gaya. Pada siklus II, guru telah melaksanakan pembelajaran dengan optimal dan bimbingan yang diberikan pun sudah dirasakan maksimal. Dalam pelaksanaan pembelajaran pada siklus II sudah tercapai indikator keberhasilan penelitian di mana tingkat ketuntasan klasikal telah mencapai di atas $80 \%$ atau bahkan telah mencapai $90 \%$. Oleh karena itu penelitian ini dihentikan hanya sampai pada siklus II dan tidak dilanjutkan pada siklus berikutnya.

\section{PEMBAHASAN}

Analisis data dilakukan dengan menggunakan teknik statistik sederhana yaitu dengan menggunakan analiasis diskriptif. Analisis diskriptif adalah model analisa dengan cara membandingkan rata-rata prosentasenya. Hasil lembar observasi terhadap peneliti selaku guru, observasi terhadap siswa, dan hasil tes evaluasi pembelajaran per siklus dapat diuraikan sebagai berikut:

\section{Rekapitulasi Hasil Observasi Terhadap Guru}

Dari hasil pengisian lembar observasi terhadap kinerja guru yang dilakukan pada saat kegiatan pembelajaran, diperoleh data seperti pada Tabel 4 .

Dari Tabel 4 dapat diketahui bahwa kinerja guru dalam melaksanakan kegiatan pembelajaran melalui pendekatan Creative Problem Solving mengalami peningkatan yang signifikan yaitu pada siklus I diperoleh skor sebesar 89 dengan prosentase keberhasilan 64\%, mengalami peningkatan pada siklus II menjadi 106 dengan prosentase keberhasilan $76 \%$ skor ideal sebesar 140 Berarti bahwa kinerja guru dalam menerapkan pendekatan Creative Problem Solving dalam kegiatan pembelajaran telah berhasil. 
Tabel 4. Rekapitulasi Hasil Observasi Terhadap Peneliti Selaku Guru

\begin{tabular}{lcccc}
\hline Aktivitas Guru & Skor Ideal & Siklus I & Silus II & Peningkatan \\
Melakukan Pembelajaran & 45 & 31 & 35 & $13 \%$ \\
Mengelola interaksi kelas & 30 & 20 & 23 & $15 \%$ \\
Mendemontrasikan & 30 & 17 & 22 & $29 \%$ \\
kemampuan khusus & & & & \\
Melaksanakan Penilaian & 15 & 9 & 11 & $22 \%$ \\
Kesan umum pelaksanaan & 20 & 12 & 15 & $25 \%$ \\
pembelajaran & & & & \\
\hline Jumlah & 89 & \multicolumn{3}{|c}{$106 \%$} \\
\hline prosentase & $64 \%$ & & $76 \%$ \\
\hline
\end{tabular}

2. Rekapitulasi Hasil Observasi Terhadap Siswa

Dari hasil pengisian lembar observasi terhadap siswa yang dilakukan pada saat kegiatan pembelajaran, diperoleh data seperti pada Tabel 5.

Tabel 5. Rekapitulasi Hasil Observasi Terhadap Siswa

\begin{tabular}{lcc}
\hline Aktivitas Belajar & $\begin{array}{c}\text { Banyak Siswa } \\
\text { Siklus I }\end{array}$ & $\begin{array}{c}\text { Banyak Siswa } \\
\text { Siklus II }\end{array}$ \\
\hline Tinggi & 5 & 9 \\
Sedang & 20 & 21 \\
Rendah & 15 & 10 \\
\hline Jumlah & 40 & 40 \\
\hline Prosentase & 62,5 & $75 \%$ \\
\hline
\end{tabular}

Dari Tabel 5 dapat diketahui bahwa pencapaian skor observasi terhadap siswa pada siklus I sebesar $62,5 \%$, yang mengalami peningkatan pada siklus II menjadi $75 \%$ dari skor ideal sebesar $100 \%$. Hal ini menunjukkan bahwa partisipasi dan keaktifan siswa dalam kegiatan pembelajaran mengalami peningkatan setiap siklusnya. Berarti bahwa penerapan pembelajaran melalui pendekatan Creative Problem Solving dapat meningkatkan partisipasi dan keaktifan siswa dalam kegiatan pembelajaran.

\section{Rekapitulasi Hasil Tes Evaluasi}

Dari hasil tes evaluasi pembelajaran untuk mengetahui hasil belajar siswa mengalami kenaikan yang signifikan. Kenaikan hasil belajar siswa dipengaruhi oleh beberapa faktor, diantaranya saat kegiatan pembelajaran pada siklus II, siswa lebih mudah memahami materi pelajaran dibandingkan pada pra siklus dan siklus I. Selain itu, siswa sudah mulai terlibat aktif dalam kegiatan pembelajaran mulai dari perhatian siswa, keberanian bertanya dan menjawab pertanyaan guru, sehingga siswa lebih mampu dalam mengerjakan soal evaluasi. Hasil tersebut menunjukkan bahwa perbaikan pembelajaran khususnya peningkatan pemahaman siswa tentang jenis jenis gaya 
dapat tercapai. Hal ini terlihat dari adanya peningkatan hasil belajar dari sebelum dilakukannya perbaikan pra siklus, siklus 1 sampai dengan Siklus II.

Dari hasil kegiatan pembelajaran pada siklus II terlihat jelas bahwa proses pembelajaran sudah cukup optimal, guru dan siswa bersama-sama terlibat dalam aktivitas pembelajaran. Hal ini bisa terlihat dari hasil penilaian dan pengamatan pada siklus II adanya kenaikan penyerapan siswa terhadap materi yang diajarkan secara signifikan. Hal ini dimungkinkan guru dalam kegiatan pembelajarannya melakukan perubahan-perubahan dan memperbaiki kekurangan-kekurangan yang dialami pada siklus I.

\section{SIMPULAN}

Dari hasil penelitian penerapan pendekatan creative problem solving pada pembelajaran IPA materi konsep gaya di kelas IV SDN Kalibuntu dapat disimpulkan sebagai berikut:

1. Dengan menerapkan pendekatan creative problem solving proses belajar mengajar di kelas menjadi lebih efektif sehingga siswa dapat terlibat aktif dan kreatif dalam pembelajaran.

2. Siswa kelas IV SDN Kalibuntu dapat menguasai konsep gaya dengan lebih efektif setelah diterapkannya pendekatan creative problem solving. Hal ini terlihat dari peningkatan prosentase ketuntasan hasil belajar siklus I yaitu $52,50 \%$ dan siklus II yaitu $87,50 \%$.

3. Aktivitas siswa kelas IV SDN Kalibuntu dalam proses kegiatan belajar pada konsep gaya dengan menerapkan pendekatan creative problem solving meningkat. Siswa aktif bertanya dan mengemukakan pendapat baik dalam kegiatan apersepsi maupun kegiatan inti pembelajaran.

4. Hasil belajar siswa kelas IV SDN Kalibuntu pada materi konsep gaya menignkat dari siklus I sebesar $52,50 \%$ dan siklus II sebsesar $77,50 \%$.

\section{REFERENSI}

Cahyono, A. N. (2007). Pengembangan Model Creative Problem Solving berbasis Teknologi dalam Pembelajaran Matematika di SMA. Tesis. Pendidikan Matematika Program Pascasarjana Universitas Negeri Semarang.

Mulyoto. (2005). Efektivitas Strategi Pemecahan Masalah Kreatif dan Analisis Sumber Belajar. Dalam B. Suryosubroto, Proses Belajar Mengajar di Sekolah (2009) (hal. 200). Jakarta: Rineka Cipta.

Pepkin, K. (2004). Creative Problem Solving In Math. Dalam I. K. Mahardika, Maryani, \& S. Murti. Jurnal Pembelajaran Fisika, Vol. 1, No. 2, September 2012

Sudjana, N. (2001). Penilaian Hasil Belajar Mengajar. Dalam Maisaroh, \& Roestrieningsih, Jurnal Ekonomi dan Pendidikan, Vol. 8 No. 2, November 2010 (hal. 157-172). Yogyakarta: Univ. Negeri Yogyakarta.

Suryosubroto, B. (2009). Proses Belajar Mengajar di Sekolah, Wawancara Baru, Beberapa Metode Pendukung dan Beberapa komponen Layanan Khusus. Jakarta: Rineka Cipta. 